\title{
Innate Lymphoid Cells in Mucosal Immunity
}

\author{
Santosh K. Panda and Marco Colonna* \\ Department of Pathology and Immunology, Washington University School of Medicine, St. Louis, MO, United States
}

Innate lymphoid cells (ILCs) are innate counterparts of T cells that contribute to immune responses by secreting effector cytokines and regulating the functions of other innate and adaptive immune cells. ILCs carry out some unique functions but share some tasks with T cells. ILCs are present in lymphoid and non-lymphoid organs and are particularly abundant at the mucosal barriers, where they are exposed to allergens, commensal microbes, and pathogens. The impact of ILCs in mucosal immune responses has been extensively investigated in the gastrointestinal and respiratory tracts, as well as in the oral cavity. Here we review the state-of-the-art knowledge of ILC functions in infections, allergy and autoimmune disorders of the mucosal barriers.

Keywords: ILCs, NK cells, mucosal infections, COPD, IBD - Inflammatory bowel diseases, allergy and asthma

\section{INTRODUCTION}

OPEN ACCESS

Edited by:

Jessica Borger,

Monash University, Australia

Reviewed by:

Ya-Jen Chang,

Academia Sinica, Taiwan

Christoph Wilhelm,

University of Bonn, Germany

*Correspondence:

Marco Colonna

mcolonna@wustl.edu

Specialty section:

This article was submitted to NK and Innate Lymphoid Cell Biology,

a section of the journal

Frontiers in Immunology

Received: 11 February 2019 Accepted: 03 April 2019

Published: 07 May 2019

Citation:

Panda SK and Colonna M (2019) Innate Lymphoid Cells in Mucosal Immunity. Front. Immunol. 10:861.

doi: 10.3389/fimmu.2019.00861
ILCs are a family of lymphocytes comprising the innate counterparts of T cells. They are poised to secrete cytokines that respond swiftly to pathogenic tissue damage and shape subsequent adaptive immunity (1). While lacking antigen-specific receptors, ILCs detect changes in the microenvironment through receptors for cytokines that are released upon tissue damage, as well as a broad range of receptors for nutrient components, microbial products, lipid mediators, and neuronal transmitters. Found in both lymphoid and non-lymphoid tissues, ILCs are primarily tissue resident cells and are particularly abundant at the mucosal surfaces of the intestine and lung, whereas they are extremely rare in peripheral blood $(2,3)$. Based on the signature cytokines they produce, their phenotype, and their developmental pathways, ILCs are divided into three major groups: ILC1s, ILC2s, and ILC3s. Two additional immune cell types, NK cells and lymphoid tissue inducer (LTi) cells, are generally included in the ILC family because their phenotypic, developmental and functional properties overlap considerably with those of ILC1s and ILC3s, respectively (4).

ILC1s secrete IFN- $\gamma$ in response to IL-12, IL-15, and IL-18. IFN- $\gamma$ promotes the ability of macrophages and DCs to eliminate intracellular bacteria and to present antigens by inducing expression of MHC and adhesion molecules. The features and functions typical of ILC1s largely overlap with those of NK cells, which also produce IFN- $\gamma$. In mice, ILC1s and NK cells both express NKp46 and NK1.1: in humans, both cell types express CD56 and NKp46 (5). A subset of human ILC1s that lacks CD56 and expresses CD127 has also been reported (6). In both humans and mice, ILC1s express markers of tissue residency, such as CD49a and CD103, as well as tissue retention, like CD69, whereas NK cells express markers indicative of recirculation through blood, including CD62L, CCR7, and S1PR $(4,7)$. Based on higher expression of perforin and granzymes, NK cells have more cytolytic potential than do ILC1s $(4,8)$. ILC1s can kill target cells through the cell death-inducing molecule TRAIL. In mice, the differentiation of ILC1s requires the transcription factors Hobit and T-bet, whereas NK cells rely on T-bet and Eomes (9-11). However, the expression 
of these transcription factors in human ILC1s and NK cells does not follow the clear pattern seen in mice. In fact, while human intraepithelial ILC1s express Eomes (5, 12), human hepatic NK cells do not (13), Moreover, differential expression of Eomes during distinct developmental stages of NK cells has been observed (14).

ILC2s, the innate counterparts of Th2, secrete type-2 cytokines such as IL-5, IL-9, IL-13, and amphiregulin in response to TSLP, IL-25, and IL-33. IL-13 plays crucial roles in the expulsion of helminths. Moreover, IL-13 and amphiregulin help repair the tissue damage engendered by helminth and viral infections (15-17). In humans, ILC2s express CRTH2, KLRG1, ST2, and CD25 $(18,19)$. Although human and mouse ILC2s share many surface markers, expression of CD44 and CD161 differs between the two. Mouse ILC2s express CD44 but not CD161 whereas human ILC2s invert this phenotype and express CD161 but not CD44 (4, 20). ILC2 development depends on the transcription factors GATA3, ROR $\alpha$, and TCF-1 in mice (21-23). GATA3 is also required for maintenance of ILC2 number in vivo and its effector function in mice $(22,24)$. Further, it was demonstrated that GATA3 is required for activation of human ILC2s (25). Although ILC2s are considered homogenous, they are classified into two groups based on their responsiveness to IL-33 and IL25 . IL-33 responsive ILC2s present in the steady state are called natural ILC2s (nILC2), whereas IL-25 responsive ILC2s elicited upon exposure to IL-25 or helminth infection are referred to as inflammatory ILC2s (iILC2) $(26,27)$. nILC2s are demarcated by elevated expression of Thy1 and ST2 along with relatively little KLRG1; in comparison, ilLC2s express more KLRG1, less Thy1 and almost no ST2 on the cell surface $(26,27)$. Another subpopulation of ILC2s that produce IL-10 (ILC2 10 ) has also been identified (28). ILC $2_{10}$ can be induced by IL33 or papain and are transcriptionally distinct; moreover this population undergoes contraction when the stimulus is removed and the few remaining ILC $2_{10}$ can be promptly activated upon restimulation (28).

Because ILC3s produce IL-22 and IL-17 in response to IL23 and IL-1 $\beta$, they are considered the innate counterparts of Th17. IL-22 stimulates the secretion of antimicrobial peptides by epithelial cells and mucus production by goblet cells, thereby supporting barrier integrity in the intestine (Figure 1) (29-31). Moreover, it promotes the differentiation of epithelial cells from intestinal stem cells (32). IL-17 promotes granulopoiesis and the secretion of neutrophil chemoattractant (33). ILC3s also produce additional cytokines such as IL-26 (in humans), GMCSF and TNF- $\alpha(34,35)$. GM-CSF sustains the generation and survival of myeloid cells, like gut DCs, that promote generation of tolerogenic commensal-specific T cells (35). The differentiation of ILC 3 s is driven by the transcription factors ROR $\gamma \mathrm{t}$ and AHR $(36,37)$. Like ILC3s, LTi are dependent on ROR $\gamma \mathrm{t}$ and secrete IL-22 and IL-17. In the embryo, LTi drive the development of secondary lymphoid organs, including lymph nodes and Peyer's patches, through the expression of lymphotoxin (LT) that engages LT $\beta$ receptor on stromal organizer cells. In the adult, LTi cells cluster to form intestinal cryptopatches, which expand into B cell-rich isolated lymphoid follicles (37-40). In humans, ILC3s express NKp44, CD127, c-Kit, and CCR6. In mice, ILC3s express also CD127, c-Kit, but include $\mathrm{CCR}^{+} \mathrm{NKp}^{-} 6^{-} \mathrm{LTi}$ as well as $\mathrm{CCR}^{-} \mathrm{NKp}^{-} 6^{-}$and $\mathrm{CCR} 6^{-} \mathrm{NKp} 46^{+}$subsets.

Since ILCs mainly populate mucosal sites, this review focuses on how these cells typically contribute to maintenance of barrier integrity and protection against various pathogenic challenges, as well as their propensity to promote allergic and autoimmune diseases when inappropriately stimulated. We individually review the impact of ILCs in the respiratory and gastrointestinal tracts as well as the oral mucosa and discuss potential targeting of ILCs for therapeutic intervention in human diseases.

\section{ILCs IN THE RESPIRATORY TRACT MUCOSA AND LUNGS}

ILCs are present throughout all segments of the respiratory tract. While ILC2s are the predominant ILC population in mice, ILC3s dominate the human respiratory tract $(2,41)$. However, the composition and functions of ILC subsets dynamically change during experimental mice models of pathology and human diseases.

\section{ILCs IN RESPIRATORY INFECTIONS}

Experiments in mice have shown that ILC2s promote epithelial and goblet cell proliferation and mucus production in the $\mathrm{H} 1 \mathrm{~N} 1$ influenza virus infection model through secretion of amphiregulin and IL-13 (15). These ILC2 functions contribute to restore lung epithelial integrity. Accordingly, antibodymediated depletion of ILC2s compromised lung function during H1N1 influenza infection. However, a study by Chang et al. demonstrated that ILC2s play a pathogenic role through IL-13 production in the $\mathrm{H} 3 \mathrm{~N} 1$ influenza infection model that induces airway hyper-reactivity, a cardinal feature of asthma (42). H3N1induced airway hyper-reactivity was attenuated in $\mathrm{Il13}-/-$ mice, whereas adoptive transfer of ILC2s restored this response (42). The reason for this discrepancy in the impact of ILC2s is yet to be deciphered; perhaps the differential virulence of the $\mathrm{H} 1 \mathrm{~N} 1$ and $\mathrm{H} 3 \mathrm{~N} 1$ viral strains used in these models is responsible. ILC2s also provide defense against helminth infection of the lung through the production of IL-9, IL-13, and amphiregulin (Figure 1) (16, 17, 43). A recent study by Huang et al. demonstrated that the KLRG1 $^{\text {hi }} \mathrm{ST}^{-}{ }^{-}$ILC2s that protect the lung from helminthinduced tissue damage originate in the intestine and migrate from the intestine to the lung during infection (17).

NK cells and ILC1s contribute to immune responses against viruses through secretion of IFN- $\gamma$ (Figure 1). NK cells play dual roles during influenza infection. Increased virus accumulation in the lung was observed in the absence of NK cells (44-46). However, depletion of NK cells rendered mice more resistant and able to survive severe influenza infection (47). Furthermore, adoptive transfer of NK cells obtained from influenza-infected lungs into mice newly infected with influenza exacerbated the disease (47). ILC1s protect from Sendai virus and influenza infection by robust secretion of IFN- $\gamma$ in experimental models (48). Beneficial roles for NK cells, ILC1s and ILC2s have been demonstrated in other mouse models of lung viral infections, 


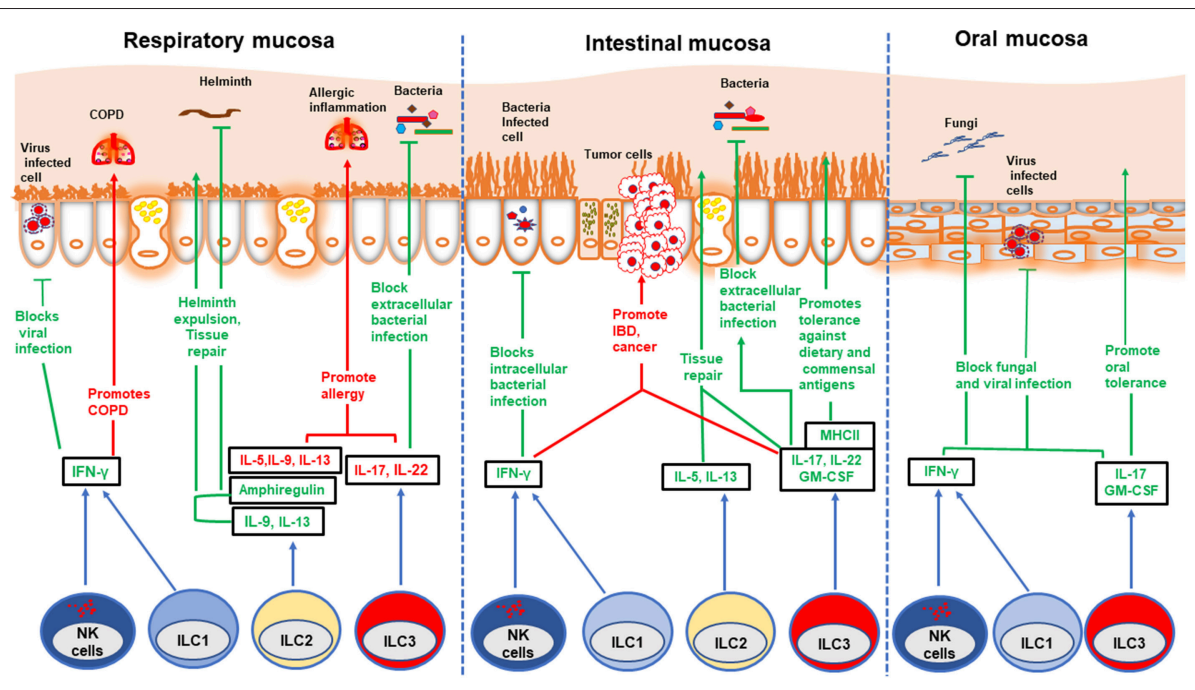

FIGURE 1 | Role of ILCs in different mucosae. Different ILC subsets play beneficial and detrimental roles in different mucosae: protection against various infections, tolerance against innocuous antigens, induction of allergy, IBD, and cancer. NK cells and ILC1s block viral and intracellular bacterial infections by secreting IFN- $\gamma$. However, ILC1s promote COPD and IBD in respiratory and intestinal mucosa, respectively. ILC2s contribute to worm expulsion and tissue repair in both respiratory and intestinal mucosa during helminth infection. Further, these cells repair viral induced lung injury by secreting amphiregulin. On the other hand, ILC2s promote allergic inflammation in lung and nasal polyps. ILC3s play dual role in both respiratory and intestinal mucosa. These cells confer protection against extracellular bacterial infection by secreting IL-22 which induces production of anti-microbial peptides by epithelial cells. ILC3s block oral fungal infection in an IL-17-dependent manner. These cells also promote tolerance against commensal and dietary antigens through MHC-II mediated antigen presentation. However, inappropriate activation of ILC3s can play a detrimental role by instigating allergy in the respiratory mucosa, as well as IBD and cancer in the intestinal mucosa.

such as rhinovirus $(49,50)$ and respiratory syncytial virus (RSV) $(49,51)$. Finally, ILC3s have also been implicated in lung infections and inflammation. Lung ILC3s play a protective role in S. pneumonia infected mice through secretion of IL-17 and IL22 (Figure 1) (52). Despite the abundance of studies in mouse models, the role of ILCs in human respiratory infections is yet to be deciphered (Table 1).

\section{ILCs IN ASTHMA}

Multiple studies concur that ILC2s play a pathogenic role during lung allergy and inflammation (Figure 1) (73, 74). Mice lacking ILCs, T cells, and B cells developed less airway inflammation than did mice lacking only $\mathrm{T}$ cells and $\mathrm{B}$ cells in the papain-induced eosinophilic asthma model $(56,75)$. Furthermore, adoptive transfer of ILC2s was sufficient to induce airway inflammation in the absence of B and T cells (75). ILC2s initiate allergic lung inflammation by secreting IL-13, which promotes migration of activated DCs to the draining lymph node where they prime Th2 differentiation (56). Lung ILC2s promoted proliferation and antibody production by $\mathrm{B} 1$ and $\mathrm{B} 2$ cells in vitro and contributed to enhanced production of IgM in vivo in an experimental model of polysaccharide-mediated nasal allergy (76). Moreover, ILC2s acquired a memory-like phenotype after primary encounter with allergen and more readily promoted allergic inflammation in the lung upon secondary encounter with unrelated allergens than did naïve ILC2s (77).

In human, expansion of ILC2s and elevated type-2 cytokines have been observed in a variety of patients with allergic asthma (Table 1). Approximately twice as many ILC2s were found in the peripheral blood of allergic asthmatic patients than in healthy controls (60). In addition, ILC2s from allergic asthmatic patients were hyper-responsive to IL-33 and IL-25 and secreted significantly higher amounts of IL-5 and IL-13 than did ILC2s from healthy controls (60). Smith et al. reported higher percentages of ILC2s in the blood and sputum of prednisonedependent severe eosinophilic asthma patients than in the blood of asymptomatic patients with steroid-naive mild atopic asthma or healthy controls (78). Respiratory allergen challenge of patients with allergic asthma elicited a sudden increase and rapid activation of ILC2s primed to secrete IL-5 and IL-13 (79). Further supporting a role for ILC2s in allergic asthma, the frequency of ILC2s and the levels of IL-33 in the bronchoalveolar lavage (BAL) of patients with allergic asthma were positively correlated with severity of the disease (80). Likewise, the percentage of ILC2s was higher in the peripheral blood of patients with eosinophilic asthma and positively correlated with eosinophil counts in the sputum (81). Similarly, the frequency of ILC2s was higher in the blood and BAL of children with severe therapy-resistant asthma than in children with recurrent lower respiratory tract infections (82). Finally, an increase of ILC2s in the BAL of patients with idiopathic pulmonary fibrosis has also been observed (83).

How other ILCs impact asthma is less clear. ILC3s have been suggested to play a pathogenic role in asthma patients. Numbers of IL-17-producing ILC3s in the human lung positively correlate with severity of the disease (57). IL-22 production by ILC3s has also been implicated in asthma pathogenesis, as asthma patients have increased levels of IL-22 compared to healthy controls (84). In mice, NK cells and ILC1s that produce IFN- $\gamma$ inhibit ILC2 expansion and type- 2 cytokine production $(85,86)$ and hence 
TABLE 1 | Role of ILCs in different mucosa of humans and mice.

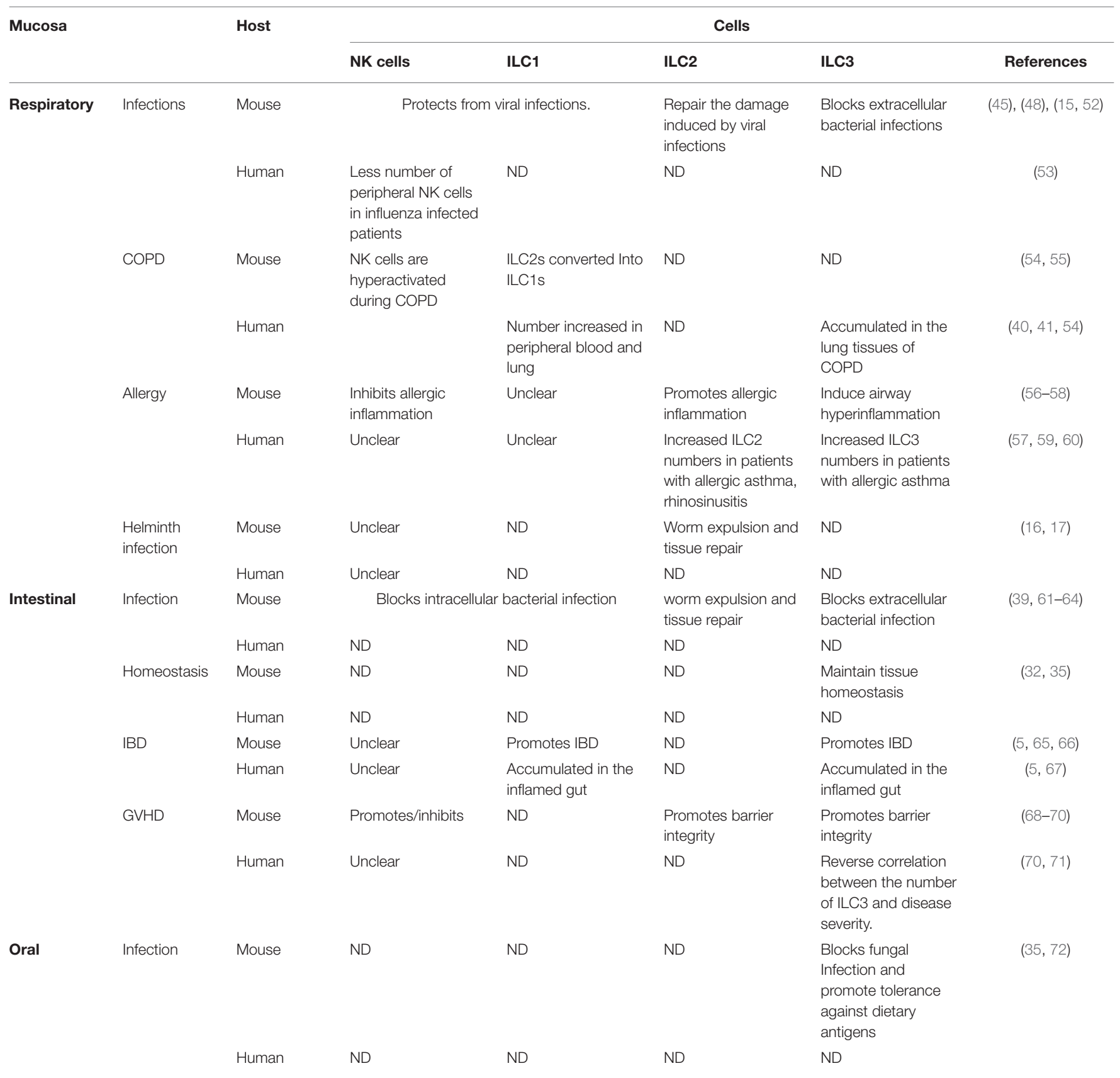

ND, Not defined.

might help control the disease. Consistent with this, depletion of NK cells during the early stages of papain-induced lung allergy in mice resulted in increased ILC2-mediated cytokine production, which exacerbated pathology (58). Furthermore, Han et al. demonstrated that IFN- $\gamma$ inhibits expansion of IL-13 producing ILC2s and attenuates the development of rhinovirusinduced asthma pathology in baby mice (87). Altogether, these studies suggest that ILC1s and NK cells attenuate the initiation and progression of allergic inflammation in the lung in mouse models. However, the role of NK cells in human allergic asthma is unclear. A human study documented fewer NK cells in the peripheral blood of severe asthma patients than in healthy controls, as well as an enrichment of the CD56 ${ }^{\text {bright }} \mathrm{NK}$ cell subset in the BAL of asthmatic patients, whereas no significant difference in the frequency of ILC2s was detected in the blood of controls, severe, and mild asthma patients (88). One report described increased frequency of an unusual population of NK cells that produces IL- 4 rather than IFN- $\gamma$ in the blood of asthmatic patients (89). In contrast, another study showed that heightened IFN- $\gamma$ responses in the airways of patients 
were associated with severe asthma, which often involves mixed granulocytic inflammation that includes neutrophils as well as eosinophils (90). Supporting a role of IFN- $\gamma$ in initiation of airway hyper responsiveness these authors showed that in a mouse model mimicking human severe asthma IFN $-\gamma^{-/-}$mice failed to exhibit the symptoms of severe asthma as compared to wild type controls (90). Further research in human patients focusing on NK cells, ILC1s, and ILC2s in both blood and inflamed tissue might decipher how the balance between different subsets of ILCs impacts asthma pathogenesis.

\section{ILCs IN ALLERGIC RHINITIS}

ILC2s have also been implicated in the pathogenesis of allergic rhinitis. The frequency of ILC2s was elevated in nasal polyps characteristic of chronic rhino-sinusitis and aspirin-exacerbated respiratory disease and positively correlated with disease severity $(18,41,59,91,92)$. Recruitment of ILC2s to the nasal mucosa upon a nasal mucosal challenge in subjects with allergic rhinitis was demonstrated in human volunteers (93). TSLP produced by epithelial cells and IL-4 produced by eosinophils induces ILC2 activation and secretion of IL-4, IL-5, and IL-13; this activates eosinophils and thereby elicits a positive feedback loop. Disrupting this loop with anti-IL-5 antibodies was beneficial for treating chronic rhino-sinusitis in humans (94, 95). More ILC2s have been noted in the peripheral blood of allergic rhinitis patients than in blood from healthy controls $(96,97)$. Moreover, the response to house dust mite-specific immunotherapy negatively correlated with ILC2 numbers; patients with a good response to the allergen-specific immunotherapy had relatively few ILC2s (97). Furthermore, subcutaneous allergen therapy resulted in fewer circulating ILC2s in patients with allergic rhinitis (98). In contrast, NK cells appear to play a beneficial role in allergic rhinitis, as patients had fewer circulating CD56 $6^{\text {bright }}$ NK cells than did healthy controls (99).

\section{ILCS IN CHRONIC OBSTRUCTIVE PULMONARY DISEASE OF THE LUNG AND CANCER}

Chronic obstructive pulmonary disease (COPD) is a disorder caused by cigarette smoke or long-term inhalation of noxious gases, which damage the upper and lower airways, eventually causing bronchitis and emphysema (100). Studies in mice and humans have demonstrated that lung resident ILC2s acquire an ILC1 phenotype and secrete IFN- $\gamma$ during COPD $(41,54)$. Furthermore, ILC1 numbers were increased in the peripheral blood of patients with severe COPD (Table 1). Additionally, a high ILC1-to-ILC2 ratio in the blood of COPD patients positively correlated with severity of the disease (54). Shikhagaie et al. reported significantly increased numbers of neuropilin ${ }^{+}$ILC3s in the lungs of patients with COPD, which were associated with formation of ectopic lymphoid aggregates (40). Further supporting a role for ILC3s in COPD, IL-17 was found to accumulate in the lungs of COPD patients (101).
In contrast to their deleterious effect in COPD, ILCs may be beneficial in lung cancer. ILC3s have been reported to congregate in human non-small cell lung carcinoma tissues where they may play a protective role by promoting the formation of tertiary lymphoid structures (102). The role of NK cells in lung cancer remains confusing, but should become more well-defined as better reagents/methods to detect NK cells and relevant activating and inhibiting receptors are developed and widely used. An early study that employed CD57, which is not specific for NK cells, found that the presence of tumor infiltrating $\mathrm{CD} 7^{+}$cells was associated with a better prognosis in patients with primary squamous cell lung carcinoma (SCLC) (103). A more recent study suggested that infiltration of $\mathrm{CD} 16^{+} \mathrm{CD} 56^{+}$ NK cells in the tumor periphery correlated with increased survival time of patients with non-small-cell lung carcinoma (NSCLC) (104). This study also noted that intra-tumoral NK cells downregulated activating receptors, including NKG2D, and upregulated the inhibitory receptor NKG2A in a mouse model of metastatic human large cell lung cancer. Consistent with this, Platonova et al. reported that intra-tumoral NK cells in NSCLC patients have an altered phenotype, with decreased expression of activating receptors such as NKp30, NKG2D, NKp80 and increased expression of the inhibitory receptor NKG2A (105). Along these lines, Carrega et al. found that most NK cells infiltrating NSCLC were CD56 ${ }^{\text {bright }} \mathrm{CD} 16^{-}$; the intra-tumoral NK cells had less cytotoxic potential than did NK cells in the peripheral blood and lung, but retained the ability to secrete IFN- $\gamma$ and TNF- $\alpha$ (106). However, Hodge et al. reported that $\mathrm{NK}$ cells (as well as NKT, $\mathrm{CD}^{+}$and $\mathrm{CD}^{+}{ }^{+} \mathrm{T}$ cells) isolated from lung cancer tissue secreted less perforin, granzyme $\mathrm{B}$, IFN- $\gamma$, TNF- $\alpha$ after stimulation than did NK, NKT, and T cells isolated from healthy tissue (107). Finally, Christmas et al. found that while the frequency of peripheral NK cells did not differ between patients with NSCLC or SCLC and healthy controls, NK cells isolated from cancer patients had diminished expression of NKp46, CD25, and perforin A and were functionally impaired in terms of cytoxicity and cytokine production (108). Collectively, these studies suggest that the tumor microenvironment either recruits NK cells with limited cytotoxic potential or, more likely, directly alters the phenotype of NK cells in order to escape from NK cell-mediated anti-tumor responses. Further research in human patients is warranted to delineate the precise role of ILCs in lung cancer.

\section{THE IMPACT OF ILCs ON INTESTINAL MUCOSA}

ILC3s are the most abundant subset of ILCs in both the fetal and adult human intestine (8). In contrast, the distribution pattern of ILC1s and ILC2s changes during development. In the fetal intestine ILC2s prevail over ILC1s, whereas ILC1s assume the dominant role in the adult intestine $(8,18)$. ILCs are unevenly distributed throughout the segments of the gastro-intestinal (GI) tract. The upper GI tract, e.g., esophagus, is enriched with ILC1s, whereas the distal part of the ileum and colon are chiefly populated by ILC3s (109). 


\section{ILCs IN GASTROINTESTINAL TRACT INFECTIONS}

The role of ILCs in intestinal infection has been demonstrated in various experimental models (Table 1); ILC3s participate in the immune responses to Citrobacter rodentium, Clostridium difficile, Salmonella enterica, Listeria monocytogenes, and Toxoplasma gondii $(10,39,63,110-112)$. Further work has shown that ILC3s restrict colonization of segmented filamentous bacteria in the gut (113) and inhibit the invasion of Alcaligenes species into Peyer's patches (114). ILC3s counter bacterial infections through secretion of IL-22, which stimulates epithelial cells to produce antimicrobial peptides (Figure 1) (31). Furthermore, IL22 induces fucosyltransferase 2 expression in intestinal epithelial cells, which promotes fucosylation of surface proteins that are shed into the lumen. These fucosylated proteins release fucose, which is metabolized by microbes as an energy source. Fucose metabolism has been shown to suppress virulent gene expression in commensal bacteria (115), and Goto et al. demonstrated that the absence of epithelial cell fucosylation renders mice more susceptible to Salmonella infection (62). IL-22 production is mainly stimulated by IL- 23 and IL- $1 \beta$ produced by inflammatory monocytes, macrophages and DCs. TNF-like ligand 1A produced by mononuclear phagocytes upon interaction with microbiota in the gut also induces IL-22 production by ILC3s and promotes healing of mucosal layer during DSS-induced acute colitis (116).

ILC1s and NK cells help combat intracellular pathogens such as T. gondii, L. monocytogenes, Salmonella typhimurium and viruses through IFN- $\gamma$ production $(10,117,118)$. ILC1s cooperate with ILC3s in providing protection against intestinal C. difficile infection (112); accordingly, rapid infection and death ensue in the absence of IFN- $\gamma$ and IL-22. By secreting IL-5 and IL-13, ILC2s induce goblet cell differentiation and mucus production that propels worm expulsion and protects from tissue damage $(61,64,119,120)$. Finally, while most studies have focused on bacterial infections, ILCs may also impact intestinal viral infections. Studies in mice have shown a protective role for ILC3s during rotavirus infections, in which IL-22 synergizes with IFN- $\lambda$ in inducing STAT1 activation (121). Recently, a cross-sectional study reported that the colons of HIV1 infected patients are enriched with NKp44 ${ }^{+}$ILC1s that produce IFN- $\gamma$ (122).

While the above studies support a critical role for ILCs in maintaining barrier integrity that protects mice from a variety of infections, one study has suggested that ILCs are completely redundant. Vely et al. studied SCID patients following allogeneic hematopoietic stem cell transplants that reconstituted the $\mathrm{T}$ cell compartment but not the ILC compartment. These patients did not manifest an increased risk of infections and other complications (123). Further research in human subjects addressing these issues is warranted.

\section{ILCs IN AUTOIMMUNITY}

ILCs have been extensively studied in intestinal autoimmune disorders, particularly inflammatory bowel disease (IBD)
(Table 1). Crohn's disease (CD) and ulcerative colitis (UC) are the two main forms of IBD that affect distinct layers of the gut wall and colonic mucosa. Although the mechanisms underpinning IBD remain incompletely understood, immune responses against commensal microbes in the intestine have long been implicated. The role of ILC3s in IBD is unclear. Several papers have proposed that ILC3s may contribute to autoimmunity. IL-23, the key activator of ILC3s, has been shown to drive colitis (124). Accumulation of ILC3s in inflamed colons of Helicobacter hepaticus infected mice has been reported (65). Moreover, mice either depleted of or genetically modified to lack ILC3s were resistant to colitis (65). Similarly, IL-17producing ILC3s have been shown to drive colitis, whereas administration of anti-IL-17 antibodies ameliorated disease (125). ILC3s also drove intestinal inflammation and pathology in the anti-CD40 model of innate colitis mice through secretion of IL-22 and GM-CSF (66). In agreement with this study, Pearson et al. demonstrated that ILC3-mediated production of GM-CSF recruits inflammatory monocytes into the intestine, which sustain intestinal inflammation (126). Corroborating these findings in humans, IL-17-producing ILC3s have been found to accumulate in the inflamed colons of patients with CD (127). Other studies have proposed a tolerogenic role for ILC3s during intestinal inflammation. ILC3s express MHC class II and can present commensal bacteria to $\mathrm{T}$ cells. However, because they lack costimulatory molecules, ILC3s are unable to elicit commensal-specific $\mathrm{CD} 4^{+} \mathrm{T}$ cells and, in fact, induce $\mathrm{T}$ cell tolerance and mitigate inflammation in mouse models $(128,129)$. Consistent with this, unusually low expression of MHC-II has been observed on colonic ILC3s from pediatric IBD patients (128). A similar role for ILC3s in maintaining tolerance against dietary and innocuous commensal antigens has also been reported $(35,129,130)$.

ILC1s have also been implicated in human IBD (Table 1). $\mathrm{CD}_{127^{+}}$lamina propria ILC1s and $\mathrm{CD} 127^{-}$intra-epithelial ILC1s amass in the inflamed intestine of CD patients $(5,8)$. Interestingly, expansion of IFN- $\gamma$ producing cells with an NK cell phenotype in the lamina propria of CD patients was accompanied by a reciprocal decrease in IL-22 producing $\mathrm{NKp}_{4} 4^{+}$ILC3s (131). Li et al. also observed that the frequency of ILC1s rises in the inflamed ileum of CD patients, whereas frequency of ILC3s declines (132). The increase in ILC1 frequency at the cost of ILC3s might be due to plasticity of ILC3s, which transdifferentiate into ILC1s under the influence of IL12 and/or IL-23 produced by myeloid cells (12). Increased frequency of $\mathrm{Lin}^{-} \mathrm{CD} 127^{+}$ILC1s in the colons of patients with IBD and primary sclerosing cholangitis has also been observed. Furthermore, these authors have demonstrated that the frequency of ILC1s drops in the blood of patients, suggesting that ILC1s are recruited into the inflamed tissue (133).

ILC2s have also been implicated in intestinal inflammation. Expansion of IL-13 producing ILC2s has been shown to play a detrimental role in oxazolone-induced colitis (134). However, expansion of amphiregulin-producing ILC2s has been shown to contribute to tissue repair during DSS-induced colitis (135). Thus, ILC2s may either promote or block intestinal pathogenesis, depending on the disease setting. ILC2s have been noted 
in intestinal samples from CD patients (19). Interestingly, these ILCs secreted IFN- $\gamma$, reflecting the plasticity of ILC2s during intestinal inflammation. Increased ILC2 frequency that positively correlates with severity of the disease has been observed in patients with eosinophilic oesophagitis (136). While accumulation of ILCs in the intestine of CD patients has been demonstrated, whether ILCs are involved in UC remains unclear. In fact, Gwela et al. reported no difference in ILC frequencies between UC patients and healthy controls (133).

In addition to autoimmunity, intestinal tissue damage can be induced by chemotherapy and radiotherapy. In this case, ILC3s help repair intestinal damage by secreting IL-22 $(68,137)$. During graft-vs.-host disease (GVHD), which can occur in leukemic patients after allogeneic hematopoietic stem cell transplant, allogeneic T cells can attack and destroy ILC3s, thereby depleting intestinal IL-22. In mice with acute GVHD, ILC3s secreted significantly less IL-22, resulting in impaired epithelial functions (Table 1) (68). Corroborating a role for ILC3s and ILC3-secreted IL-22 in tissue repair and resolution of inflammation during GVHD, fewer ILC3s were observed in patients with acute or chronic GVHD than in patients that did not develop GVHD, (71). Furthermore, recovery of gut homing $\mathrm{CD}^{+} 9^{+}$activated ILC3s was associated with a lower incidence of GVHD (71). Finally, infusion of donor ILC2s after bone marrow transplant reduced the lethality of GVHD up to $70 \%$ and enhanced the barrier function of the GI tract in an allogenic stem cell transplant model (69). Altogether, these studies support a beneficial role for ILC2s and ILC3s in prognosis of GVHD.

\section{ILCs IN INTESTINAL CANCER}

It has been known for long time that IBD patients have an increased risk of intestinal cancer due to chronic inflammation
(138). Given that ILCs accumulate in the intestinal mucosa during IBD, they could contribute to the inflammatory environment and may play a pro-tumorigenic role. Indeed, the key activator of ILC3s, IL-23, and the ILC3 effector cytokines IL-17 and IL-22 are associated with both experimental and clinical tumorigenesis (Figure 1) (139-142). In contrast to ILC3s, NK cells and ILC1s may have anti-tumorigenic effects through secretion of IFN- $\gamma$. A decreased frequency of NK cells expressing NKp30, NKp46, and NKG2D paralleled by an increased frequency of ILC2s was noted in the peripheral blood of gastric cancer patients in comparison to healthy controls (143). Similarly, serum levels of IFN- $\gamma$ in gastric cancer patients were lower than those found in healthy donors $(144,145)$. Although infiltration of NK cells into gastric cancer tissues is scarce (146), the presence of intratumoral NK cells correlated with a better prognosis (147). While these studies suggest that ILCs are involved in the pathogenesis of intestinal cancer, further studies in human patients is required to address their exact role.

\section{ILCs IN THE ORAL MUCOSA}

Like the intestinal mucosa, the oral mucosa is populated with commensal microflora and exposed to dietary antigens and pathogens. Thus, ILCs present in the oral mucosa may help maintain barrier function and protect against pathogenic infections. Human ILC3s and intraepithelial ILC1s were originally identified in tonsils, which are secondary lymphoid tissues coated by the oral mucosa $(5,34)$. ILCs have been also found in human gingivae. Approximately $10-15 \%$ of total $\mathrm{CD}^{2} 5^{+}$cells identified were ILCs and most of them were IFN- $\gamma$ secreting ILC1s (148). A recent study by Brown et al. demonstrated the presence of all

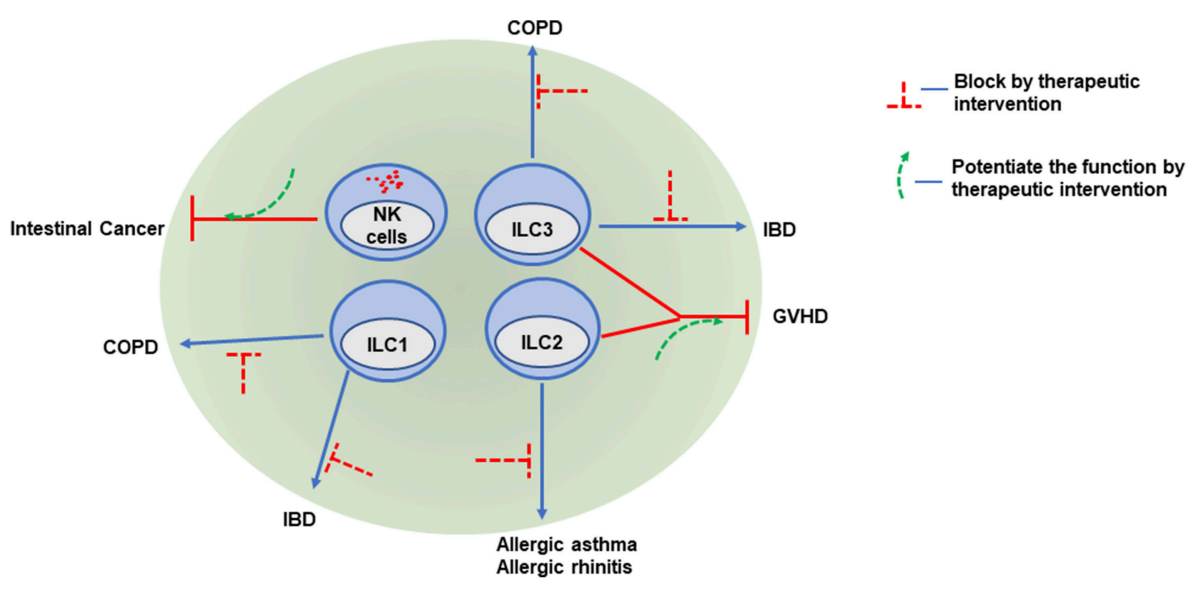

FIGURE 2 | ILCs as potential therapeutic targets. Because of their various roles in promoting or attenuating pathogenesis, ILCs may be potential therapeutic target. Infiltration of NK cells into intestinal cancer is associated with better prognosis, therefore increasing NK cell infiltration and potentiating NK cell functions in tumors might be beneficial. Hyperactivation of both ILC1 and ILC3 promote COPD and IBD. Regulation of pathogenic cytokine production or antibody mediated depletion of these cells might be a potential treatment option. Similarly, antibodies targeting type-2 cytokines produced by ILC2 may be promising in the treatment of allergy and asthma patients. Both ILC2 and ILC3 ameliorate clinical symptoms and play protective roles in GVHD. Expansion of ILC2 and ILC3 numbers by therapeutic intervention might be helpful to control GVHD. 
three groups of ILCs in the murine gingivae (149). ILC3s provided protection against oropharyngeal infection with Candida albicans through production of IL-17A and IL-17F induced by IL-23 (Figure 1) (72); thus, both Ror $\gamma t^{-/-}$mice lacking ILC3s and mice depleted of ILC3s by antibody treatment suffered severe infection (72). IFN- $\gamma$-producing ILC1s and NK cells have been found in the oral mucosa of macaques. During simian immunodeficiency virus infection, expansion of ILC1s and increased IFN- $\gamma$ production were noted in the oral draining lymph nodes and tonsils whereas NK cells remained unchanged (150). Future research will decipher the impact of ILCs in oral immune responses to commensals and dietary antigens.

\section{TARGETING ILCs FOR THERAPY}

A strong rationale for developing therapies specifically targeting ILCs, such as depleting or agonistic antibodies, depends on whether ILCs play unique, non-redundant roles in the context of various diseases, which is yet to be firmly established. However, evidence from both experimental mice models and humans has suggested that therapeutic targeting of ILCs might be beneficial for autoimmune disorders. Depletion of Thy-1 positive ILCs was beneficial for treating $H$. hepaticus induced colitis (65). Similarly, depletion of ILC2s blocked the development of papain-induced allergy (75). When ILCs and T cells have redundant functions, an alternative option is to neutralize the effector cytokines produced by both ILCs and T cells. Blockade of the IL-17 receptor or neutralizing IL-17 and IFN- $\gamma$ in several clinical trials failed to ameliorate IBD $(151,152)$. However, targeting both IL-17 and IFN- $\gamma$ bore promising results in preclinical models (65). Blockade of cytokines that stimulate IL-17 and IFN- $\gamma$ secretion, such as IL-12 and IL-23 or IL-23 alone, has also been effective for treating CD patients $(153,154)$. Since GVHD is associated with fewer IL-22-producing ILC3s, enhancement of ILC3 numbers and function might be explored for the treatment of GVHD (Figure 2) $(68,71)$.

Several attempts have been made to explore the efficacy of targeting ILC2s in respiratory diseases. Anti-IL-5 and anti-IL-4 receptor $\alpha$ treatments have had promising effects in treating patients suffering from chronic rhinosinusitis with nasal polyps and eosinophilic asthma (94, 155, 156). Similarly, inhibiting ILC2 functions with CRTH2 antagonists can restore lung function in asthma patients (Figure 2) $(157,158)$. Further research and well-designed clinical studies

\section{REFERENCES}

1. Bando JK, Colonna M. Innate lymphoid cell function in the context of adaptive immunity. Nat Immunol. (2016) 17:783-9. doi: 10.1038/ ni. 3484

2. Mjosberg J, Spits H. Human innate lymphoid cells. J Allergy Clin Immunol. (2016) 138:1265-76. doi: 10.1016/j.jaci.2016.09.009

3. Ebbo M, Crinier A, Vely F, Vivier E. Innate lymphoid cells: major players in inflammatory diseases. Nat Rev Immunol. (2017) 17:665-78. doi: $10.1038 /$ nri.2017.86 should help delineate the efficacy of targeting ILCs in various mucosal diseases.

\section{FUTURE PERSPECTIVES}

ILCs appear to contribute significantly to human health and disease, playing beneficial roles in some mucosal infections and GVHD, while aggravating pathology in IBD and COPD. Are ILCs a valid therapeutic target? To address this question, it is important to understand whether ILCs play unique roles or are largely redundant with $\mathrm{T}$ cells. Studies in mouse models have provided limited answers, as they are mainly performed in RAG-deficient mice that lack adaptive responses. Animal models in which ILCs are selectively ablated in the presence of intact adaptive responses are underdeveloped. Most human studies describe single timepoint assays that provide a snapshot of ILCs at a particular stage of the disease. Longitudinal studies addressing multiple subsets of ILCs at different stages of disease is warranted to provide a clearer picture of their impact. For instance, while NK cells seem to control lung ILC2 expansion in asthma, it is important to understand whether NK-ILC2 cross-talk occurs at a particular stage or throughout the disease. Similarly, ILC3 secretion of IL-17 and IFN- $\gamma$ seems to be detrimental in IBD, whereas IL-22 secretion may be protective. Thus, it is essential to examine the ratio of ILC3s producing IL$17 /$ IFN- $\gamma$ and IL-22 at different stages of the disease. Although ethical constraints and limitations of available tissue restrict human studies, further analysis including diverse age groups and focusing on different stages of disease would help better understand the role of ILCs as well as how they might be targeted for the therapy of mucosal diseases.

\section{AUTHOR CONTRIBUTIONS}

SP wrote the first draft. MC contributed to conceiving and writing the manuscript.

\section{FUNDING}

MC is supported by NIH grants AI095542, DE025884, AI134236, and AI134035. MC receives research support from Pfizer.

\section{ACKNOWLEDGMENTS}

We thank Susan Gilfillan for critical comments.
4. Vivier E, Artis D, Colonna M, Diefenbach A, Di Santo JP, Eberl G, et al. Innate lymphoid cells: 10 years on. Cell. (2018) 174:1054-66. doi: 10.1016/j.cell.2018.07.017

5. Fuchs A, Vermi W, Lee JS, Lonardi S, Gilfillan S, Newberry RD, et al. Intraepithelial type 1 innate lymphoid cells are a unique subset of IL-12- and IL-15-responsive IFN-gamma-producing cells. Immunity. (2013) 38:769-81. doi: 10.1016/j.immuni.20 13.02 .010

6. Simoni Y, Fehlings M, Kloverpris HN, McGovern N, Koo SL, Loh CY, et al. Human innate lymphoid cell subsets possess tissue-type based 
heterogeneity in phenotype and frequency. Immunity. (2017) 46:148-61. doi: 10.1016/j.immuni.2016.11.005

7. Cortez VS, Robinette ML, Colonna M. Innate lymphoid cells: new insights into function and development. Curr Opin Immunol. (2015) 32:71-7. doi: 10.1016/j.coi.2015.01.004

8. Bernink JH, Peters CP, Munneke M, te Velde AA, Meijer SL, Weijer K, et al. Human type 1 innate lymphoid cells accumulate in inflamed mucosal tissues. Nat Immunol. (2013) 14:221-9. doi: 10.1038/ni.2534

9. Gordon SM, Chaix J, Rupp LJ, Wu J, Madera S, Sun JC, et al. The transcription factors T-bet and Eomes control key checkpoints of natural killer cell maturation. Immunity. (2012) 36:55-67. doi: 10.1016/j.immuni.2011.11.016

10. Klose CSN, Flach M, Mohle L, Rogell L, Hoyler T, Ebert K, et al. Differentiation of type 1 ILCs from a common progenitor to all helper-like innate lymphoid cell lineages. Cell. (2014) 157:340-56. doi: 10.1016/j.cell.2014.03.030

11. Mackay LK, Minnich M, Kragten NA, Liao Y, Nota B, Seillet C, et al. Hobit and Blimp1 instruct a universal transcriptional program of tissue residency in lymphocytes. Science. (2016) 352:459-63. doi: 10.1126/science.aad2035

12. Bernink JH, Krabbendam L, Germar K, de Jong E, Gronke K, Kofoed-Nielsen $\mathrm{M}$, et al. Interleukin-12 and -23 control plasticity of $\mathrm{CD} 127(+)$ group 1 and group 3 innate lymphoid cells in the intestinal lamina propria. Immunity. (2015) 43:146-60. doi: 10.1016/j.immuni.2015.06.019

13. Marquardt N, Beziat V, Nystrom S, Hengst J, Ivarsson MA, Kekalainen E, et al. Cutting edge: identification and characterization of human intrahepatic CD49a+ NK cells. J Immunol. (2015) 194:2467-71. doi: 10.4049/jimmunol.1402756

14. Collins A, Rothman N, Liu K, Reiner SL. Eomesodermin and T-bet mark developmentally distinct human natural killer cells. JCI Insight. (2017) 2:e90063. doi: 10.1172/jci.insight.90063

15. Monticelli LA, Sonnenberg GF, Abt MC, Alenghat T, Ziegler CG, Doering TA, et al. Innate lymphoid cells promote lung-tissue homeostasis after infection with influenza virus. Nat Immunol. (2011) 12:1045-54. doi: $10.1038 /$ ni.2131

16. Turner JE, Morrison PJ, Wilhelm C, Wilson M, Ahlfors H, Renauld JC, et al. IL-9-mediated survival of type 2 innate lymphoid cells promotes damage control in helminth-induced lung inflammation. J Exp Med. (2013) 210:2951-65. doi: 10.1084/jem.20130071

17. Huang Y, Mao K, Chen X, Sun MA, Kawabe T, Li W, et al. S1P-dependent interorgan trafficking of group 2 innate lymphoid cells supports host defense. Science. (2018) 359:114-9. doi: 10.1126/science.aam5809

18. Mjosberg JM, Trifari S, Crellin NK, Peters CP, van Drunen CM, Piet B, et al. Human IL-25- and IL-33-responsive type 2 innate lymphoid cells are defined by expression of CRTH2 and CD161. Nat Immunol. (2011) 12:1055-62. doi: $10.1038 /$ ni.2104

19. Lim AI, Menegatti S, Bustamante J, Le Bourhis L, Allez M, Rogge L, et al. IL-12 drives functional plasticity of human group 2 innate lymphoid cells. $J$ Exp Med. (2016) 213:569-83. doi: 10.1084/jem.20151750

20. Hurrell BP, Shafiei Jahani P, Akbari O. Social networking of group two innate lymphoid cells in allergy and asthma. Front Immunol. (2018) 9:2694. doi: 10.3389/fimmu.2018.02694

21. Halim TY, MacLaren A, Romanish MT, Gold MJ, McNagny KM, Takei F. Retinoic-acid-receptor-related orphan nuclear receptor alpha is required for natural helper cell development and allergic inflammation. Immunity. (2012) 37:463-74. doi: 10.1016/j.immuni.2012.06.012

22. Hoyler T, Klose CS, Souabni A, Turqueti-Neves A, Pfeifer D, Rawlins EL, et al. The transcription factor GATA-3 controls cell fate and maintenance of type 2 innate lymphoid cells. Immunity. (2012) 37:634-48. doi: 10.1016/j.immuni.2012.06.020

23. Yang Q, Monticelli LA, Saenz SA, Chi AW, Sonnenberg GF, Tang J, et al. $\mathrm{T}$ cell factor 1 is required for group 2 innate lymphoid cell generation. Immunity. (2013) 38:694-704. doi: 10.1016/j.immuni.2012.12.003

24. Yagi R, Zhong C, Northrup DL, Yu F, Bouladoux N, Spencer S, et al. The transcription factor GATA3 is critical for the development of all IL7Ralpha-expressing innate lymphoid cells. Immunity. (2014) 40:378-88. doi: 10.1016/j.immuni.2014.01.012

25. Mjosberg J, Bernink J, Golebski K, Karrich JJ, Peters CP, Blom B, et al. The transcription factor GATA3 is essential for the function of human type 2 innate lymphoid cells. Immunity. (2012) 37:649-59. doi: 10.1016/j.immuni.2012.08.015

26. Huang Y, Guo L, Qiu J, Chen X, Hu-Li J, Siebenlist U, et al. IL-25-responsive, lineage-negative KLRG1(hi) cells are multipotential 'inflammatory' type 2 innate lymphoid cells. Nat Immunol. (2015) 16:161-9. doi: 10.1038/ ni.3078

27. Huang Y, Paul WE. Inflammatory group 2 innate lymphoid cells. Int Immunol. (2016) 28:23-8. doi: 10.1093/intimm/dxv044

28. Seehus CR, Kadavallore A, Torre B, Yeckes AR, Wang Y, Tang J, et al. Alternative activation generates IL-10 producing type 2 innate lymphoid cells. Nat Commun. (2017) 8:1900. doi: 10.1038/s41467-017-02023-Z

29. Aujla SJ, Chan YR, Zheng M, Fei M, Askew DJ, Pociask DA, et al. IL-22 mediates mucosal host defense against Gram-negative bacterial pneumonia. Nat Med. (2008) 14:275-81. doi: 10.1038/nm1710

30. Sugimoto K, Ogawa A, Mizoguchi E, Shimomura Y, Andoh A, Bhan AK, et al. IL-22 ameliorates intestinal inflammation in a mouse model of ulcerative colitis. J Clin Invest. (2008) 118:534-44. doi: 10.1172/JCI33194

31. Zheng Y, Valdez PA, Danilenko DM, Hu Y, Sa SM, Gong Q, et al. Interleukin22 mediates early host defense against attaching and effacing bacterial pathogens. Nat Med. (2008) 14:282-9. doi: 10.1038/nm1720

32. Lindemans CA, Calafiore M, Mertelsmann AM, O'Connor MH, Dudakov JA, Jenq RR, et al. Interleukin-22 promotes intestinal-stem-cell-mediated epithelial regeneration. Nature. (2015) 528:560-4. doi: 10.1038/nature16460

33. Stark MA, Huo Y, Burcin TL, Morris MA, Olson TS, Ley K. Phagocytosis of apoptotic neutrophils regulates granulopoiesis via IL-23 and IL-17. Immunity. (2005) 22:285-94. doi: 10.1016/j.immuni.2005.01.011

34. Cella M, Fuchs A, Vermi W, Facchetti F, Otero K, Lennerz JK, et al. A human natural killer cell subset provides an innate source of IL-22 for mucosal immunity. Nature. (2009) 457:722-5. doi: 10.1038/nature07537

35. Mortha A, Chudnovskiy A, Hashimoto D, Bogunovic M, Spencer SP, Belkaid Y, et al. Microbiota-dependent crosstalk between macrophages and ILC3 promotes intestinal homeostasis. Science. (2014) 343:1249288. doi: $10.1126 /$ science. 1249288

36. Sanos SL, Bui VL, Mortha A, Oberle K, Heners C, Johner C, et al. RORgammat and commensal microflora are required for the differentiation of mucosal interleukin 22-producing NKp46+ cells. Nat Immunol. (2009) 10:83-91. doi: 10.1038/ni.1684

37. Lee JS, Cella M, McDonald KG, Garlanda C, Kennedy GD, Nukaya M, et al. AHR drives the development of gut ILC22 cells and postnatal lymphoid tissues via pathways dependent on and independent of Notch. Nat Immunol. (2011) 13:144-51. doi: 10.1038/ni.2187

38. Eberl G, Marmon S, Sunshine MJ, Rennert PD, Choi Y, Littman DR. An essential function for the nuclear receptor RORgamma $(t)$ in the generation of fetal lymphoid tissue inducer cells. Nat Immunol. (2004) 5:64-73. doi: $10.1038 /$ ni1022

39. Klose CS, Kiss EA, Schwierzeck V, Ebert K, Hoyler T, d'Hargues Y, et al. A T-bet gradient controls the fate and function of CCR6-RORgammat+ innate lymphoid cells. Nature. (2013) 494:261-5. doi: 10.1038/nature11813

40. Shikhagaie MM, Bjorklund AK, Mjosberg J, Erjefalt JS, Cornelissen AS, Ros XR, et al. Neuropilin-1 is expressed on lymphoid tissue residing lti-like group 3 innate lymphoid cells and associated with ectopic lymphoid aggregates. Cell Rep. (2017) 18:1761-73. doi: 10.1016/j.celrep.2017.01.063

41. Bal SM, Bernink JH, Nagasawa M, Groot J, Shikhagaie MM, Golebski K, et al. IL-1beta, IL-4 and IL-12 control the fate of group 2 innate lymphoid cells in human airway inflammation in the lungs. Nat Immunol. (2016) 17:636-45. doi: $10.1038 /$ ni.3444

42. Chang YJ, Kim HY, Albacker LA, Baumgarth N, McKenzie AN, Smith $\mathrm{DE}$, et al. Innate lymphoid cells mediate influenza-induced airway hyperreactivity independently of adaptive immunity. Nat Immunol. (2011). 12:631-8. doi: 10.1038/ni.2045

43. Mohapatra A, Van Dyken SJ, Schneider C, Nussbaum JC, Liang HE, Locksley RM. Group 2 innate lymphoid cells utilize the IRF4-IL-9 module to coordinate epithelial cell maintenance of lung homeostasis. Mucosal Immunol. (2016) 9:275-86. doi: 10.1038/mi.2015.59

44. Nogusa S, Ritz BW, Kassim SH, Jennings SR, Gardner EM. Characterization of age-related changes in natural killer cells during primary influenza infection in mice. Mech Ageing Dev. (2008) 129:223-30. doi: 10.1016/j.mad.2008.01.003 
45. Abboud G, Tahiliani V, Desai P, Varkoly K, Driver J, Hutchinson TE, et al. Natural killer cells and innate interferon gamma participate in the host defense against respiratory vaccinia virus infection. J Virol. (2016) 90:129-41. doi: 10.1128/JVI.01894-15

46. Li T, Wang J, Wang Y, Chen Y, Wei H, Sun R, et al. Respiratory influenza virus infection induces memory-like liver NK cells in mice. J Immunol. (2017) 198:1242-52. doi: 10.4049/jimmunol. 1502186

47. Zhou G, Juang SW, Kane KP. NK cells exacerbate the pathology of influenza virus infection in mice. Eur J Immunol. (2013) 43:929-38. doi: $10.1002 /$ eji.201242620

48. Weizman OE, Adams NM, Schuster IS, Krishna C, Pritykin Y, Lau C, et al. ILC1 confer early host protection at initial sites of viral infection. Cell. (2017) 171:795-808 e712. doi: 10.1016/j.cell.2017.09.052

49. Kaiko GE, Phipps S, Angkasekwinai P, Dong C, Foster PS. NK cell deficiency predisposes to viral-induced Th2-type allergic inflammation via epithelial-derived IL-25. J Immunol. (2010) 185:4681-90. doi: 10.4049/jimmunol.1001758

50. Jayaraman A, Jackson DJ, Message SD, Pearson RM, Aniscenko J, Caramori G, et al. IL-15 complexes induce NK- and T-cell responses independent of type I IFN signaling during rhinovirus infection. Mucosal Immunol. (2014) 7:1151-64. doi: 10.1038/mi.2014.2

51. Stier MT, Bloodworth MH, Toki S, Newcomb DC, Goleniewska K, Boyd KL, et al. Respiratory syncytial virus infection activates IL-13-producing group 2 innate lymphoid cells through thymic stromal lymphopoietin. J Allergy Clin Immunol. (2016) 138:814-24 e811. doi: 10.1016/j.jaci.2016.01.050

52. Van Maele L, Carnoy C, Cayet D, Ivanov S, Porte R, Deruy E, et al. Activation of Type 3 innate lymphoid cells and interleukin 22 secretion in the lungs during Streptococcus pneumoniae infection. J Infect Dis. (2014) 210:493-503. doi: 10.1093/infdis/jiu106

53. Jost S, Quillay H, Reardon J, Peterson E, Simmons RP, Parry BA, et al. Changes in cytokine levels and NK cell activation associated with influenza. PLoS ONE. (2011) 6:e25060. doi: 10.1371/journal.pone.0025060

54. Silver JS, Kearley J, Copenhaver AM, Sanden C, Mori M, Yu L, et al. Inflammatory triggers associated with exacerbations of COPD orchestrate plasticity of group 2 innate lymphoid cells in the lungs. Nat Immunol. (2016) 17:626-35. doi: 10.1038/ni.3443

55. Kim JH, Jang YJ. Role of Natural Killer Cells in Airway Inflammation. Allergy Asthma Immunol Res. (2018) 10:448-56. doi: 10.4168/aair.2018.10.5.448

56. Halim TY, Steer CA, Matha L, Gold MJ, Martinez-Gonzalez I, McNagny $\mathrm{KM}$, et al. Group 2 innate lymphoid cells are critical for the initiation of adaptive $\mathrm{T}$ helper 2 cell-mediated allergic lung inflammation. Immunity. (2014) 40:425-35. doi: 10.1016/j.immuni.2014.01.011

57. Kim HY, Lee HJ, Chang YJ, Pichavant M, Shore SA, Fitzgerald KA, et al. Interleukin-17-producing innate lymphoid cells and the NLRP3 inflammasome facilitate obesity-associated airway hyperreactivity. Nat Med. (2014) 20:54-61. doi: 10.1038/nm.3423

58. Bi J, Cui L, Yu G, Yang X, Chen Y, Wan X. NK cells alleviate lung inflammation by negatively regulating group 2 innate lymphoid cells. $J$ Immunol. (2017) 198:3336-44. doi: 10.4049/jimmunol.1601830

59. Shaw JL, Fakhri S, Citardi MJ, Porter PC, Corry DB, Kheradmand F, et al. IL-33-responsive innate lymphoid cells are an important source of IL-13 in chronic rhinosinusitis with nasal polyps. Am J Respir Crit Care Med. (2013) 188:432-9. doi: 10.1164/rccm.201212-2227OC

60. Bartemes KR, Kephart GM, Fox SJ, Kita H. Enhanced innate type 2 immune response in peripheral blood from patients with asthma. J Allergy Clin Immunol. (2014) 134:671-8 e674. doi: 10.1016/j.jaci.2014.06.024

61. Price AE, Liang HE, Sullivan BM, Reinhardt RL, Eisley CJ, Erle DJ, et al. Systemically dispersed innate IL-13-expressing cells in type 2 immunity. Proc Natl Acad Sci USA. (2011) 107:11489-94. doi: 10.1073/pnas.100 3988107

62. Goto Y, Obata T, Kunisawa J, Sato S, Ivanov II, Lamichhane A, et al. Innate lymphoid cells regulate intestinal epithelial cell glycosylation. Science. (2014) 345:1254009. doi: 10.1126/science. 1254009

63. Guo X, Qiu J, Tu T, Yang X, Deng L, Anders RA, et al. Induction of innate lymphoid cell-derived interleukin- 22 by the transcription factor STAT3 mediates protection against intestinal infection. Immunity. (2014) 40:25-39. doi: 10.1016/j.immuni.2013.10.021
64. Waddell A, Vallance JE, Hummel A, Alenghat T, Rosen MJ. IL33 induces murine intestinal goblet cell differentiation indirectly via innate lymphoid cell IL-13 secretion. J Immunol. (2018) 202:598-607. doi: 10.4049/jimmunol.1800292

65. Buonocore S, Ahern PP, Uhlig HH, Ivanov II, Littman DR, Maloy KJ, et al. Innate lymphoid cells drive interleukin-23-dependent innate intestinal pathology. Nature. (2010) 464:1371-5. doi: 10.1038/nature08949

66. Song C, Lee JS, Gilfillan S, Robinette ML, Newberry RD, Stappenbeck $\mathrm{TS}$, et al. Unique and redundant functions of NKp46+ ILC3s in models of intestinal inflammation. J Exp Med. (2015) 212:1869-82. doi: $10.1084 /$ jem. 20151403

67. Geremia A, Jewell DP. The IL-23/IL-17 pathway in inflammatory bowel disease. Exp Rev Gastroenterol Hepatol. (2012) 6:223-37. doi: 10.1586/egh.11.107

68. Hanash AM, Dudakov JA, Hua G, O’Connor MH, Young LF, Singer NV, et al. Interleukin-22 protects intestinal stem cells from immune-mediated tissue damage and regulates sensitivity to graft vs. host disease. Immunity. (2012) 37:339-50. doi: 10.1016/j.immuni.2012.05.028

69. Bruce DW, Stefanski HE, Vincent BG, Dant TA, Reisdorf S, Bommiasamy $\mathrm{H}$, et al. Type 2 innate lymphoid cells treat and prevent acute gastrointestinal graft-vs.-host disease. J Clin Invest. (2017) 127:1813-25. doi: 10.1172/JCI91816

70. Simonetta F, Alvarez M, Negrin RS. Natural killer cells in graft-vs.-hostdisease after allogeneic hematopoietic cell transplantation. Front Immunol. (2017) 8:465. doi: 10.3389/fimmu.2017.00465

71. Munneke JM, Bjorklund AT, Mjosberg JM, Garming-Legert K, Bernink $\mathrm{JH}$, Blom B, et al. Activated innate lymphoid cells are associated with a reduced susceptibility to graft-vs.-host disease. Blood. (2014) 124:812-21. doi: 10.1182/blood-2013-11-536888

72. Gladiator A, Wangler N, Trautwein-Weidner K, LeibundGut-Landmann S. Cutting edge: IL-17-secreting innate lymphoid cells are essential for host defense against fungal infection. J Immunol. (2013) 190:521-5. doi: 10.4049/jimmunol.1202924

73. Martinez-Gonzalez I, Steer CA, Takei F. Lung ILC2s link innate and adaptive responses in allergic inflammation. Trends Immunol. (2015) 36:189-95. doi: 10.1016/j.it.2015.01.005

74. Cheng H, Jin C, Wu J, Zhu S, Liu YJ, Chen J. Guards at the gate: physiological and pathological roles of tissue-resident innate lymphoid cells in the lung. Protein Cell. (2017) 8:878-95. doi: 10.1007/s13238-017-0379-5

75. Halim TY, Krauss RH, Sun AC, Takei F. Lung natural helper cells are a critical source of Th2 cell-type cytokines in protease allergen-induced airway inflammation. Immunity. (2012) 36:451-63. doi: 10.1016/j.immuni.2011.12.020

76. Drake LY, Iijima K, Bartemes K, Kita H. Group 2 innate lymphoid cells promote an early antibody response to a respiratory antigen in mice. $J$ Immunol. (2016) 197:1335-42. doi: 10.4049/jimmunol.1502669

77. Martinez-Gonzalez I, Matha L, Steer CA, Ghaedi M, Poon GF, Takei F. Allergen-experienced group 2 innate lymphoid cells acquire memorylike properties and enhance allergic lung inflammation. Immunity. (2016) 45:198-208. doi: 10.1016/j.immuni.2016.06.017

78. Smith SG, Chen R, Kjarsgaard M, Huang C, Oliveria JP, O’Byrne PM, et al. Increased numbers of activated group 2 innate lymphoid cells in the airways of patients with severe asthma and persistent airway eosinophilia. J Allergy Clin Immunol. (2016) 137:75-86 e78. doi: 10.1016/j.jaci.2015.05.037

79. Chen R, Smith SG, Salter B, El-Gammal A, Oliveria JP, Obminski C, et al. Allergen-induced Increases in Sputum Levels of Group 2 Innate Lymphoid Cells in Subjects with Asthma. Am J Respir Crit Care Med. (2017) 196:700-12. doi: 10.1164/rccm.201612-2427OC

80. Christianson CA, Goplen NP, Zafar I, Irvin C, Good JT Jr, Rollins DR, et al. Persistence of asthma requires multiple feedback circuits involving type 2 innate lymphoid cells and IL-33. J Allergy Clin Immunol. (2015) 136:59-68 e14. doi: 10.1016/j.jaci.2014.11.037

81. Liu T, Wu J, Zhao J, Wang J, Zhang Y, Liu L, et al. Type 2 innate lymphoid cells: a novel biomarker of eosinophilic airway inflammation in patients with mild to moderate asthma. Respir Med. (2015) 109:1391-6. doi: 10.1016/j.rmed.2015.09.016

82. Nagakumar P, Denney L, Fleming L, Bush A, Lloyd CM, Saglani S. Type 2 innate lymphoid cells in induced sputum from children with severe 
asthma. J Allergy Clin Immunol. (2016) 137:624-6 e626. doi: 10.1016/j.jaci. 2015.06.038

83. Hams E, Armstrong ME, Barlow JL, Saunders SP, Schwartz C, Cooke G, et al. IL-25 and type 2 innate lymphoid cells induce pulmonary fibrosis. Proc Natl Acad Sci USA. (2014) 111:367-72. doi: 10.1073/pnas.1315854111

84. Besnard AG, Sabat R, Dumoutier L, Renauld JC, Willart M, Lambrecht B, et al. Dual role of IL-22 in allergic airway inflammation and its cross-talk with IL-17A. Am J Respir Crit Care Med. (2011) 183:1153-63. doi: 10.1164/rccm.201008-1383OC

85. Molofsky AB, Van Gool F, Liang HE, Van Dyken SJ, Nussbaum JC, Lee J, et al. Interleukin-33 and interferon-gamma counter-regulate group 2 innate lymphoid cell activation during immune perturbation. Immunity. (2015) 43:161-74. doi: 10.1016/j.immuni.2015.05.019

86. Moro K, Kabata H, Tanabe M, Koga S, Takeno N, Mochizuki M, et al. Interferon and IL-27 antagonize the function of group 2 innate lymphoid cells and type 2 innate immune responses. Nat Immunol. (2016) 17:76-86. doi: 10.1038/ni.3309

87. Han M, Hong JY, Jaipalli S, Rajput C, Lei J, Hinde JL, et al. IFN-gamma blocks development of an asthma phenotype in rhinovirus-infected baby mice by inhibiting type 2 innate lymphoid cells. Am J Respir Cell Mol Biol. (2017) 56:242-51. doi: $10.1165 / \mathrm{rcmb} .2016-0056 \mathrm{OC}$

88. Barnig C, Cernadas M, Dutile S, Liu X, Perrella MA, Kazani S, et al. Lipoxin A4 regulates natural killer cell and type 2 innate lymphoid cell activation in asthma. Sci Transl Med. (2013) 5:174ra126. doi: $10.1126 /$ scitranslmed. 3004812

89. Wei H, Zhang J, Xiao W, Feng J, Sun R, Tian Z. Involvement of human natural killer cells in asthma pathogenesis: natural killer 2 cells in type 2 cytokine predominance. J Allergy Clin Immunol. (2005) 115:841-7. doi: 10.1016/j.jaci.2004.11.026

90. Raundhal M, Morse C, Khare A, Oriss TB, Milosevic J, Trudeau J, et al. High IFN-gamma and low SLPI mark severe asthma in mice and humans. J Clin Invest. (2015) 125:3037-50. doi: 10.1172/JCI80911

91. Eastman JJ, Cavagnero KJ, Deconde AS, Kim AS, Karta MR, Broide DH, et al. Group 2 innate lymphoid cells are recruited to the nasal mucosa in patients with aspirin-exacerbated respiratory disease. J Allergy Clin Immunol. (2017) 140:101-8 e103. doi: 10.1016/j.jaci.2016.11.023

92. Poposki JA, Klingler AI, Tan BK, Soroosh P, Banie H, Lewis G, et al. Group 2 innate lymphoid cells are elevated and activated in chronic rhinosinusitis with nasal polyps. Immun Inflamm Dis. (2017) 5:233-43. doi: 10.1002/iid 3.161

93. Dhariwal J, Cameron A, Trujillo-Torralbo MB, Del Rosario A, Bakhsoliani E, Paulsen M, et al. Mucosal type 2 innate lymphoid cells are a key component of the allergic response to aeroallergens. Am J Respir Crit Care Med. (2017) 195:1586-96. doi: 10.1164/rccm.201609-1846OC

94. Gevaert P, Van Bruaene N, Cattaert T, Van Steen K, Van Zele T, Acke F, et al. Mepolizumab, a humanized anti-IL-5 mAb, as a treatment option for severe nasal polyposis. J Allergy Clin Immunol. (2011) 128:989-95 e981-988. doi: 10.1016/j.jaci.2011.07.056

95. Rivero A, Liang J. Anti-IgE and anti-il5 biologic therapy in the treatment of nasal polyposis: a systematic review and meta-analysis. Ann Otol Rhinol Laryngol. (2017) 126:739-47. doi: 10.1177/0003489417731782

96. Fan D, Wang X, Wang M, Wang Y, Zhang L, Li Y, et al. Allergendependent differences in ilc2s frequencies in patients with allergic rhinitis. Allergy Asthma Immunol Res. (2016) 8:216-22. doi: 10.4168/aair. 2016.8.3.216

97. Mitthamsiri W, Pradubpongsa P, Sangasapaviliya A, Boonpiyathad T. Decreased CRTH2 expression and response to allergen restimulation on innate lymphoid cells in patients with allergen-specific immunotherapy. Allergy Asthma Immunol Res. (2018) 10:662-74. doi: 10.4168/aair.2018.10.6.662

98. Lao-Araya M, Steveling E, Scadding GW, Durham SR, Shamji MH. Seasonal increases in peripheral innate lymphoid type 2 cells are inhibited by subcutaneous grass pollen immunotherapy. J Allergy Clin Immunol. (2014) 134:1193-5 e1194. doi: 10.1016/j.jaci.2014.07.029

99. Scordamaglia F, Balsamo M, Scordamaglia A, Moretta A, Mingari MC, Canonica GW, et al. Perturbations of natural killer cell regulatory functions in respiratory allergic diseases. J Allergy Clin Immunol.(2008) 121:479-85. doi: $10.1016 /$ j.jaci.2007.09.047
100. Brusselle GG, Joos GF, Bracke KR. New insights into the immunology of chronic obstructive pulmonary disease. Lancet. (2011) 378:1015-26. doi: 10.1016/S0140-6736(11)60988-4

101. Roos AB, Sanden C, Mori M, Bjermer L, Stampfli MR, Erjefalt JS. IL-17A is elevated in end-stage chronic obstructive pulmonary disease and contributes to cigarette smoke-induced lymphoid neogenesis. Am J Respir Crit Care Med. (2015) 191:1232-41. doi: 10.1164/rccm.201410-1861OC

102. Carrega P, Loiacono F, Di Carlo E, Scaramuccia A, Mora M, Conte $\mathrm{R}$, et al. NCR(+)ILC3 concentrate in human lung cancer and associate with intratumoral lymphoid structures. Nat Commun. (2015) 6:8280. doi: $10.1038 /$ ncomms 9280

103. Villegas FR, Coca S, Villarrubia VG, Jimenez R, Chillon MJ, Jareno J, et al. Prognostic significance of tumor infiltrating natural killer cells subset CD57 in patients with squamous cell lung cancer. Lung Cancer. (2002) 35:23-8.

104. Jin S, Deng Y, Hao JW, Li Y, Liu B, Yu Y, et al. NK cell phenotypic modulation in lung cancer environment. PLoS ONE. (2014) 9:e109976. doi: 10.1371/journal.pone.0109976

105. Platonova S, Cherfils-Vicini J, Damotte D, Crozet L, Vieillard V, Validire P, et al. Profound coordinated alterations of intratumoral NK cell phenotype and function in lung carcinoma. Cancer Res. (2011) 71:5412-22. doi: 10.1158/0008-5472.CAN-10-4179

106. Carrega P, Morandi B, Costa R, Frumento G, Forte G, Altavilla G, et al. Natural killer cells infiltrating human nonsmall-cell lung cancer are enriched in CD56 bright CD16(-) cells and display an impaired capability to kill tumor cells. Cancer. (2008) 112:863-75. doi: 10.1002/cncr.23239

107. Hodge G, Barnawi J, Jurisevic C, Moffat D, Holmes M, Reynolds PN, et al. Lung cancer is associated with decreased expression of perforin, granzyme $\mathrm{B}$ and interferon (IFN)-gamma by infiltrating lung tissue $\mathrm{T}$ cells, natural killer (NK) T-like and NK cells. Clin Exp Immunol. (2014) 178:79-85. doi: $10.1111 /$ cei. 12392

108. Al Omar SY, Marshall E, Middleton D, Christmas SE. Increased killer immunoglobulin-like receptor expression and functional defects in natural killer cells in lung cancer. Immunology. (2011) 133:94-104. doi: 10.1111/j.1365-2567.2011.03415.x

109. Kramer B, Goeser F, Lutz P, Glassner A, Boesecke C, Schwarze-Zander C, et al. Compartment-specific distribution of human intestinal innate lymphoid cells is altered in HIV patients under effective therapy. PLoS Pathog. (2017) 13:e1006373. doi: 10.1371/journal.ppat.1006373

110. Satoh-Takayama N, Vosshenrich CA, Lesjean-Pottier S, Sawa S, Lochner M, Rattis F, et al. Microbial flora drives interleukin 22 production in intestinal NKp46+ cells that provide innate mucosal immune defense. Immunity. (2008) 29:958-70. doi: 10.1016/j.immuni.2008.11.001

111. Reynders A, Yessaad N, Vu Manh TP, Dalod M, Fenis A, Aubry C, et al. Identity, regulation and in vivo function of gut NKp46+RORgammat+ and NKp46+RORgammat- lymphoid cells. EMBO J. (2011) 30:2934-47. doi: 10.1038/emboj.2011.201

112. Abt MC, Lewis BB, Caballero S, Xiong H, Carter RA, Susac B, et al. Innate immune defenses mediated by Two ILC subsets are critical for protection against acute clostridium difficile infection. Cell Host Microbe. (2015) 18:2737. doi: 10.1016/j.chom.2015.06.011

113. Qiu J, Guo X, Chen ZM, He L, Sonnenberg GF, Artis D, et al. Group 3 innate lymphoid cells inhibit T-cell-mediated intestinal inflammation through aryl hydrocarbon receptor signaling and regulation of microflora. Immunity. (2013) 39:386-99. doi: 10.1016/j.immuni.2013.08.002

114. Sonnenberg GF, Monticelli LA, Alenghat T, Fung TC, Hutnick NA, Kunisawa J, et al. Innate lymphoid cells promote anatomical containment of lymphoid-resident commensal bacteria. Science. (2012) 336:1321-5. doi: $10.1126 /$ science. 1222551

115. Pickard JM, Maurice CF, Kinnebrew MA, Abt MC, Schenten D, Golovkina TV, et al. Rapid fucosylation of intestinal epithelium sustains host-commensal symbiosis in sickness. Nature. (2014) 514:638-41. doi: $10.1038 /$ nature 13823

116. Castellanos JG, Woo V, Viladomiu M, Putzel G, Lima S, Diehl GE, et al. Microbiota-Induced TNF-like Ligand 1A drives group 3 innate lymphoid cell-mediated barrier protection and intestinal $t$ cell activation during colitis. Immunity. (2018) 49:1077-89 e1075. doi: 10.1016/j.immuni.2018.10.014

117. Bao S, Beagley KW, France MP, Shen J, Husband AJ. Interferongamma plays a critical role in intestinal immunity against 
Salmonella typhimurium infection. Immunology. (2000) 99:464-72. doi: 10.1046/j.1365-2567.2000.00955.x

118. Nguyen TT, Baumgarth N. Innate B cells tell ilc how it's done. Immunity. (2016) 45:8-10. doi: 10.1016/j.immuni.2016.06.030

119. Moro K, Yamada $\mathrm{T}$, Tanabe $\mathrm{M}$, Takeuchi $\mathrm{T}$, Ikawa $\mathrm{T}$, Kawamoto $\mathrm{H}$, et al. Innate production of $\mathrm{T}(\mathrm{H}) 2$ cytokines by adipose tissueassociated c-Kit(+)Sca-1(+) lymphoid cells. Nature. (2010) 463:540-4. doi: $10.1038 /$ nature 08636

120. Schneider C, O'Leary CE, von Moltke J, Liang HE, Ang QY, Turnbaugh $\mathrm{PJ}$, et al. A metabolite-triggered tuft cell-ILC2 circuit drives small intestinal remodeling. Cell. (2018) 174:271-84 e214. doi: 10.1016/j.cell. 2018.05.014

121. Hernandez PP, Mahlakoiv T, Yang I, Schwierzeck V, Nguyen N, Guendel $\mathrm{F}$, et al. Interferon-lambda and interleukin 22 act synergistically for the induction of interferon-stimulated genes and control of rotavirus infection. Nat Immunol. (2015) 16:698-707. doi: 10.1038/ ni. 3180

122. Dillon SM, Castleman MJ, Frank DN, Austin GL, Gianella S, Cogswell $\mathrm{AC}$, et al. Brief report: inflammatory colonic innate lymphoid cells are increased during untreated HIV-1 infection and associated with markers of gut dysbiosis and mucosal immune activation. J Acquir Immune Defic Syndr. (2017) 76:431-7. doi: 10.1097/QAI.0000000000001523

123. Vely F, Barlogis V, Vallentin B, Neven B, Piperoglou C, Ebbo M, et al. Evidence of innate lymphoid cell redundancy in humans. Nat Immunol. (2016) 17:1291-9. doi: 10.1038/ni.3553

124. Ahern PP, Schiering C, Buonocore S, McGeachy MJ, Cua DJ, Maloy $\mathrm{KJ}$, et al. Interleukin-23 drives intestinal inflammation through direct activity on T cells. Immunity. (2010) 33:279-88. doi: 10.1016/j.immuni. 2010.08.010

125. Powell N, Walker AW, Stolarczyk E, Canavan JB, Gokmen MR, Marks $\mathrm{E}$, et al. The transcription factor T-bet regulates intestinal inflammation mediated by interleukin-7 receptor+ innate lymphoid cells. Immunity. (2012) 37:674-84. doi: 10.1016/j.immuni.2012.09.008

126. Pearson C, Thornton EE, McKenzie B, Schaupp AL, Huskens N, Griseri T, et al. ILC3 GM-CSF production and mobilisation orchestrate acute intestinal inflammation. Elife. (2016) 5:e10066. doi: 10.7554/eLife. 10066

127. Geremia A, Arancibia-Carcamo CV, Fleming MP, Rust N, Singh B, Mortensen NJ, et al. IL-23-responsive innate lymphoid cells are increased in inflammatory bowel disease. J Exp Med. (2011) 208:1127-33. doi: 10.1084/jem.20101712

128. Hepworth MR, Monticelli LA, Fung TC, Ziegler CG, Grunberg S, Sinha $\mathrm{R}$, et al. Innate lymphoid cells regulate $\mathrm{CD} 4+\mathrm{T}$-cell responses to intestinal commensal bacteria. Nature. (2013) 498:113-7. doi: 10.1038/ nature 12240

129. Hepworth MR, Fung TC, Masur SH, Kelsen JR, McConnell FM, Dubrot J, et al. Immune tolerance. Group 3 innate lymphoid cells mediate intestinal selection of commensal bacteria-specific CD4(+) T cells. Science. (2015) 348:1031-5. doi: 10.1126/science.aaa4812

130. Stefka AT, Feehley T, Tripathi P, Qiu J, McCoy K, Mazmanian SK, et al. Commensal bacteria protect against food allergen sensitization. Proc Natl Acad Sci USA. (2014) 111:13145-50. doi: 10.1073/pnas.14 12008111

131. Takayama T, Kamada N, Chinen H, Okamoto S, Kitazume MT, Chang J, et al. Imbalance of NKp44(+)NKp46(-) and NKp44()NKp46(+) natural killer cells in the intestinal mucosa of patients with Crohn's disease. Gastroenterology. (2010) 139:882-92 e881-883. doi: 10.1053/j.gastro.2010.05.040

132. Li J, Doty AL, Iqbal A, Glover SC. The differential frequency of Lineage(-)CRTH2(-)CD45(+)NKp44(-)CD117(-)CD127(+)ILC subset in the inflamed terminal ileum of patients with Crohn's disease. Cell Immunol. (2016) 304-5, 63-8. doi: 10.1016/j.cellimm.2016.05.001

133. Gwela A, Siddhanathi P, Chapman RW, Travis S, Powrie F, ArancibiaCarcamo CV, et al. Th1 and innate lymphoid cells accumulate in primary sclerosing cholangitis-associated inflammatory bowel disease. J Crohns Colitis. (2017) 11:1124-34. doi: 10.1093/ecco-jcc/jjx050

134. Camelo A, Barlow JL, Drynan LF, Neill DR, Ballantyne SJ, Wong SH, et al. Blocking IL-25 signalling protects against gut inflammation in a type-2 model of colitis by suppressing nuocyte and NKT derived IL-13. J Gastroenterol. (2012) 47:1198-211. doi: 10.1007/s00535-012-0591-2

135. Monticelli LA, Osborne LC, Noti M, Tran SV, Zaiss DM, Artis D. IL33 promotes an innate immune pathway of intestinal tissue protection dependent on amphiregulin-EGFR interactions. Proc Natl Acad Sci USA. (2015) 112:10762-7. doi: 10.1073/pnas.1509070112

136. Doherty TA, Baum R, Newbury RO, Yang T, Dohil R, Aquino M, et al. Group 2 innate lymphocytes (ILC2) are enriched in active eosinophilic esophagitis. J Allergy Clin Immunol. (2015) 136:792-4 e793. doi: 10.1016/j.jaci. 2015.05.048

137. Aparicio-Domingo P, Romera-Hernandez M, Karrich JJ, Cornelissen F, Papazian N, Lindenbergh-Kortleve DJ, et al. Type 3 innate lymphoid cells maintain intestinal epithelial stem cells after tissue damage. J Exp Med. (2015) 212:1783-91. doi: 10.1084/jem.20150318

138. Kappelman MD, Farkas DK, Long MD, Erichsen R, Sandler RS, Sorensen HT, et al. Risk of cancer in patients with inflammatory bowel diseases: a nationwide population-based cohort study with 30 years of follow-up evaluation. Clin Gastroenterol Hepatol. (2014) 12:265-73 e261. doi: 10.1016/j.cgh.2013.03.034

139. Langowski JL, Zhang $\mathrm{X}, \mathrm{Wu} \mathrm{L}$, Mattson JD, Chen T, Smith K, et al. IL-23 promotes tumour incidence and growth. Nature. (2006) 442:461-5. doi: 10.1038 /nature04808

140. Wu S, Rhee KJ, Albesiano E, Rabizadeh S, Wu X, Yen HR, et al. A human colonic commensal promotes colon tumorigenesis via activation of T helper type 17 T cell responses. Nat Med. (2009) 15:1016-22. doi: 10.1038/ nm.2015

141. Grivennikov SI, Wang K, Mucida D, Stewart CA, Schnabl B, Jauch $\mathrm{D}$, et al. Adenoma-linked barrier defects and microbial products drive IL-23/IL-17-mediated tumour growth. Nature. (2012) 491:254-8. doi: 10.1038/nature11465

142. Kirchberger S, Royston DJ, Boulard O, Thornton E, Franchini F, Szabady RL, et al. Innate lymphoid cells sustain colon cancer through production of interleukin-22 in a mouse model. J Exp Med. (2013) 210:917-31. doi: $10.1084 /$ jem. 20122308

143. Bie Q, Zhang P, Su Z, Zheng D, Ying X, Wu Y, et al. Polarization of ILC2s in peripheral blood might contribute to immunosuppressive microenvironment in patients with gastric cancer. J Immunol Res. (2014) 2014:923135. doi: 10.1155/2014/923135

144. Lee J, Park KH, Ryu JH, Bae HJ, Choi A, Lee H, et al. Natural killer cell activity for IFN-gamma production as a supportive diagnostic marker for gastric cancer. Oncotarget. (2017) 8:70431-40. doi: 10.18632/oncotarget.19712

145. Han B, Mao FY, Zhao YL, Lv YP, Teng YS, Duan M, et al. Altered NKp30, NKp46, NKG2D, and DNAM-1 expression on circulating nk cells is associated with tumor progression in human gastric cancer. J Immunol Res. (2018) 2018:6248590. doi: 10.1155/2018/6248590

146. Halama N, Braun M, Kahlert C, Spille A, Quack C, Rahbari N, et al. Natural killer cells are scarce in colorectal carcinoma tissue despite high levels of chemokines and cytokines. Clin Cancer Res. (2011) 17:678-89. doi: 10.1158/1078-0432.CCR-10-2173

147. Ishigami S, Natsugoe S, Tokuda K, Nakajo A, Che X, Iwashige $\mathrm{H}$, et al. Prognostic value of intratumoral natural killer cells in gastric carcinoma. Cancer. (2000) 88:577-83. doi: 10.1002/(SICI)10970142(20000201)88:3<577::AID-CNCR13>3.0.CO;2-V

148. Dutzan N, Konkel JE, Greenwell-Wild T, Moutsopoulos NM. Characterization of the human immune cell network at the gingival barrier. Mucosal Immunol. (2016) 9:1163-72. doi: 10.1038/mi. 2015.136

149. Brown JL, Campbell L, Malcolm J, Adrados Planell A, Butcher JP, Culshaw S. Enrichment of innate lymphoid cell populations in gingival tissue. J Dent Res. (2018) 97:1399-405. doi: 10.1177/0022034518782141

150. Li H, Reeves RK. Functional perturbation of classical natural killer and innate lymphoid cells in the oral mucosa during SIV infection. Front Immunol. (2012) 3:417. doi: 10.3389/fimmu.2012.00417

151. Hueber W, Sands BE, Lewitzky S, Vandemeulebroecke M, Reinisch W, Higgins PD, et al. Secukinumab, a human anti-IL-17A monoclonal antibody, for moderate to severe Crohn's disease: unexpected results of a randomised, double-blind placebo-controlled trial. Gut. (2012) 61:1693-700. doi: 10.1136/gutjnl-2011-301668 
152. Kaser A. Not all monoclonals are created equal - lessons from failed drug trials in Crohn's disease. Best Pract Res Clin Gastroenterol. (2014) 28:437-49. doi: 10.1016/j.bpg.2014.04.005

153. Sands BE, Chen J, Feagan BG, Penney M, Rees WA, Danese S, et al. Efficacy and safety of MEDI2070, an antibody against interleukin 23, in patients with moderate to severe crohn's disease: a phase 2a study. Gastroenterology. (2017) 153:77-86 e76. doi: 10.1053/j.gastro.2017.03.049

154. Rutgeerts P, Gasink C, Chan D, Lang Y, Pollack P, Colombel JF, et al. Efficacy of ustekinumab for inducing endoscopic healing in patients with crohn's disease. Gastroenterology. (2018) 155:1045-58. doi: 10.1053/j.gastro.2018.06.035

155. Bagnasco D, Ferrando M, Varricchi G, Passalacqua G, Canonica GW. A critical evaluation of anti-il-13 and anti-il-4 strategies in severe asthma. Int Arch Allergy Immunol. (2016) 170:122-31. doi: 10.1159/ 000447692

156. Wenzel S, Castro M, Corren J, Maspero J, Wang L, Zhang B, et al. Dupilumab efficacy and safety in adults with uncontrolled persistent asthma despite use of medium-to-high-dose inhaled corticosteroids plus a long-acting beta2 agonist: a randomised double-blind placebocontrolled pivotal phase $2 \mathrm{~b}$ dose-ranging trial. Lancet. (2016) 388:31-44. doi: 10.1016/S0140-6736(16)30307-5
157. Okubo K, Hashiguchi K, Takeda T, Baba K, Kitagoh H, Miho H, et al. A randomized controlled phase II clinical trial comparing ONO-4053, a novel DP1 antagonist, with a leukotriene receptor antagonist pranlukast in patients with seasonal allergic rhinitis. Allergy. (2017) 72:1565-75. doi: 10.1111/all.13174

158. Singh D, Ravi A, Southworth T. CRTH2 antagonists in asthma: current perspectives. Clin Pharmacol. (2017) 9:165-73. doi: 10.2147/CPAA. S119295

Conflict of Interest Statement: MC receives research support from Pfizer.

The remaining author declares that the research was conducted in the absence of any commercial or financial relationships that could be construed as a potential conflict of interest.

Copyright (c) 2019 Panda and Colonna. This is an open-access article distributed under the terms of the Creative Commons Attribution License (CC BY). The use, distribution or reproduction in other forums is permitted, provided the original author(s) and the copyright owner(s) are credited and that the original publication in this journal is cited, in accordance with accepted academic practice. No use, distribution or reproduction is permitted which does not comply with these terms. 